\title{
Changes in bronchial responsiveness to histamine at intervals after allergen challenge
}

\author{
D W COCKCROFT, K Y MURDOCK
}

From the Section of Respiratory Medicine, Department of Medicine, University Hospital, Saskatoon, Saskatchewan, Canada

ABSTRACT Bronchial responsiveness to inhaled histamine was measured two, seven, and 30 hours after allergen inhalation challenge in 19 atopic subjects. The provocative histamine concentrations ${ }_{\mathrm{N}}$ causing a $20 \%$ fall in $\mathrm{FEV}_{1}\left(\mathrm{PC}_{20}\right)$ at these three times were compared with the baseline value, with O values obtained two and seven hours after diluent inhalation, and with those obtained five to seven $\rightarrow$ days after allergen challenge in the 12 late responders. Seven subjects had allergen induced isolated $\rightarrow$ early asthmatic responses $\left(\triangle \mathrm{FEV}_{1} 22.6 \%\right.$ (SD $\left.6 \cdot 6 \%\right)$ ) with less than a $5 \%$ late fall in $\mathrm{FEV}_{1}$. There was no change in the six histamine $\mathrm{PC}_{20}$ values measured in these seven subjects; the geometric $\vec{\oplus}$ mean $\mathrm{PC}_{20}$ was $1 \cdot 0-1 \cdot 3 \mathrm{mg} / \mathrm{ml}$ on all six occasions. Twelve subjects had an allergen induced early $\stackrel{\infty}{*}$ asthmatic response $\left(\Delta \mathrm{FEV}_{1} 26 \cdot 3 \%(9 \cdot 8 \%)\right)$ followed by a definite $\left(>15 \% \Delta \mathrm{FEV}_{1}, \mathrm{n}=7\right)$ or equivocal (5-15\% $\left.\triangle \mathrm{FEV}_{1}, \mathrm{n}=5\right)$ late asthmatic response. The geometric mean histamine $\mathrm{PC}_{20}$ was $\sum_{\leq}$ not significantly different two hours after allergen inhalation either from baseline $(0.67 v$ 을 $0.78 \mathrm{mg} / \mathrm{ml})$ or from that seen two hours after diluent $(0.67 v 0.95)$. It was significantly reduced at $\frac{\otimes}{\varnothing}$ seven $(0.24 \mathrm{mg} / \mathrm{ml})$ and at 30 hours $(0.44 \mathrm{mg} / \mathrm{ml})$ but had returned to baseline when repeated five to $\varrho$ seven days later $(0.74 \mathrm{mg} / \mathrm{ml})$. In 10 subjects with a dual response who had a repeat antigen chal- $\overrightarrow{\overrightarrow{0}}$ lenge the mean early and late response and $\Delta \mathrm{PC}_{20}$ at seven and 30 hours were similar. These data show that bronchial responsiveness to a non-allergic stimulus has not increased two hours after $\frac{\vec{F}}{0}$ allergen inhalation following spontaneous recovery of the early asthmatic response but before the start of the late asthmatic response.

Non-allergic bronchial responsiveness (for example, to inhaled histamine or methacholine) may increase after exposure to allergen ${ }^{1-3}$ or occupational sensitising agents ${ }^{45}$ in a sensitised individual. There is a close relationship between allergen or occupational induced increase in non-allergic bronchial responsiveness and the late asthmatic response. ${ }^{1-5}$ Non-allergic bronchial responsiveness does not appear to increase after isolated early asthmatic responses. ${ }^{13}$ Bronchial responsiveness to histamine or methacholine is increased seven to eight hours after allergen challenge ${ }^{124}$ towards the end of the late response and this may persist for days after the late response, at a time when all measurements of lung function have returned to baseline. ${ }^{124}$ To our knowledge, change in bronchial responsiveness in the inter-

Address for reprint requests: Dr D W Cockcroft, University Hospital, Saskatoon, Saskatchewan, Canada S7N 0XO.

Accepted 24 September 1986 val phase between the early and the late response to 3 allergen has not been examined closely. In this studyo we measured bronchial responsiveness to histamine $₹$ before and two, seven, and 30 hours after allergen 의 inhalation in 19 subjects undergoing controlled aller- $\rightarrow$ gen inhalation tests.

\section{Methods}

\section{SUBJECTS}

Nineteen subjects were selected from volunteers and patients at the respiratory clinic, University Hospital Saskatoon. All subjects had asthma, defined as $\widetilde{\mathbb{D}}$ wheezing dyspnoea on exposure to an allergen to? which they had a positive prick skin test response. Allo subjects were atopic and had an $\mathrm{FEV}_{1}$ greater than $70 \%$ of the predicted value and a histamine provocative concentration causing a $20 \%$ fall in $\mathrm{FEV}_{1} \stackrel{\mathbb{Q}}{\mathcal{Q}}$ $\left(\mathrm{PC}_{20}\right)$ of $10 \mathrm{mg} / \mathrm{ml}$ or less. They were using no medi-cation other than an inhaled $\beta_{2}$ agonist occasionally as needed $(n=7)$. The investigations were approvedo 
Table 1 Anthropometric and clinical data on the subjects

\begin{tabular}{|c|c|c|c|c|c|c|c|c|c|c|}
\hline \multirow[b]{2}{*}{ Patient No } & \multirow[b]{2}{*}{ Age } & \multirow[b]{2}{*}{ Sex } & \multirow{2}{*}{$\begin{array}{l}\text { Height } \\
(\mathrm{cm})\end{array}$} & \multirow{2}{*}{$\begin{array}{l}\text { Weight } \\
(\mathrm{kg})\end{array}$} & \multicolumn{2}{|c|}{$F E V_{1}$} & \multirow{2}{*}{$\begin{array}{l}\text { Histamine } P C_{20} \\
(\mathrm{mg} / \mathrm{ml})\end{array}$} & \multirow[b]{2}{*}{ Treatment* } & \multirow[b]{2}{*}{ Allergen $\dagger$} & \multirow{2}{*}{$\begin{array}{l}\text { Allerg } \\
\text { respon }\end{array}$} \\
\hline & & & & & (l) & ( $\%$ predicted) & & & & \\
\hline 1 & 19 & $\mathbf{M}$ & 188 & 90.9 & $5 \cdot 2$ & 109 & 8.0 & & Horse & $\mathrm{E}$ \\
\hline 2 & 18 & $\mathrm{~F}$ & 160 & $59 \cdot 0$ & $3 \cdot 1$ & 96 & 6.8 & & Cat & $E$ \\
\hline 3 & 22 & M & 173 & 80.5 & $4 \cdot 7$ & 108 & $5 \cdot 4$ & & Grass & $\bar{D}$ \\
\hline 4 & 19 & $\mathrm{~F}$ & 175 & 86.4 & $4 \cdot 1$ & 110 & 3.8 & & Cat & $\mathrm{D}$ \\
\hline 45 & 17 & $\mathrm{~F}$ & 160 & $64 \cdot 5$ & 3.6 & 110 & $3 \cdot 8$ & & Grass & D \\
\hline 6 & 23 & $\mathrm{~F}$ & 165 & $52 \cdot 7$ & 3.5 & 106 & $2 \cdot 5$ & & Horse & E \\
\hline 7 & 27 & $F$ & 160 & $84 \cdot 1$ & $3 \cdot 0$ & 101 & $2 \cdot 1$ & & Grass & D \\
\hline 8 & 28 & $\mathrm{~F}$ & 165 & $74 \cdot 5$ & $3 \cdot 7$ & 117 & $1 \cdot 2$ & & Cat & D \\
\hline 9 & 22 & $\mathrm{M}$ & 180 & $81 \cdot 8$ & $4 \cdot 2$ & 92 & $1 \cdot 2$ & & Grass & E \\
\hline 10 & 26 & $\mathrm{~F}$ & 160 & 60.9 & $3 \cdot 2$ & 100 & 0.80 & & Cat & $\mathrm{E}$ \\
\hline 11 & 23 & $\mathbf{M}$ & 178 & $73 \cdot 6$ & 4.8 & 110 & 0.58 & $*$ & Tree & D \\
\hline 12 & 20 & $\mathrm{~F}$ & 157 & $73 \cdot 2$ & $3 \cdot 2$ & 104 & 0.40 & & Cat & D \\
\hline 13 & 22 & $\mathrm{~F}$ & 165 & $63 \cdot 2$ & 3.4 & 102 & 0.40 & * & Cat & D \\
\hline 14 & 21 & $F$ & 157 & 58.9 & $3 \cdot 1$ & 100 & 0.36 & * & Horse & D \\
\hline 15 & 20 & $F$ & 165 & 56.8 & 3.4 & 102 & 0.32 & $*$ & Cat & D \\
\hline 16 & 23 & $\mathrm{~F}$ & 170 & 70.9 & $3 \cdot 1$ & 89 & $0 \cdot 20$ & $*$ & Grass & D \\
\hline 17 & 22 & $M$ & 165 & $78 \cdot 2$ & $3 \cdot 7$ & 92 & 0.20 & & Grass & E \\
\hline 18 & 58 & $F$ & 163 & $72 \cdot 3$ & $1 \cdot 6$ & 71 & $0 \cdot 14$ & $*$ & Cat & $\mathrm{E}$ \\
\hline 19 & 36 & $\mathbf{M}$ & 170 & $63 \cdot 2$ & $2 \cdot 8$ & 76 & $0 \cdot 12$ & $*$ & Grass & D \\
\hline
\end{tabular}

*Inhaled $\beta_{2}$ agonist (fenoterol or salbutamol) as needed.

†Allergens used were cat 1:10 w:v, lot No 152072306; horse $20000 \mathrm{PNU} / \mathrm{ml}$, lot No J52115501; and mixed tree pollen 1:10 w:v, lot No 1498180 (purchased Hollister Stier Laboratories, Mississauga, Ontario); mixed grass pollen 1:20 w:v, lot No X30631 (purchased from Bencard Allergy Service, Western Ont: $\mathrm{PC}_{20}$ - provocative concentration causing a $20 \%$ fall in $\mathrm{FEV}_{1}$; E-early; $\mathrm{D}$-dual.

by the President's Ethics Committee of the University of Saskatchewan and signed informed consent was obtained. Data on the subjects are shown in table 1.

\section{HISTAMINE INHALATION TEST}

Bronchial responsiveness to inhaled histamine was measured as described previously. ${ }^{67}$ Solutions were nebulised with a Wright nebuliser calibrated to give an output of $0.130 \mathrm{ml} / \mathrm{min}$ (airflow $81 \mathrm{~min}^{-1}$ ) of an aerosol whose particles had an aerodynamic mass median diameter $1-1.5 \mu \mathrm{m}$. Aerosols were inhaled by tidal breathing via a loose fitting facemask with the nose clipped. The $\mathrm{FEV}_{1}$ was measured initially in triplicate. Phosphate buffered saline (PBS), the diluent for the histamine solution, was then inhaled for two minutes and the $\mathrm{FEV}_{1}$ measurement repeated at 30 and 90 seconds. Doubling concentrations of histamine $(0.03-8.0 \mathrm{mg} / \mathrm{ml})$ were then inhaled for two minutes at five minute intervals until the $\mathrm{FEV}_{1}$, measured again at 30 and 90 seconds, had fallen at least $20 \%$ or until the highest concentration had been given. The percentage reduction in $\mathrm{FEV}_{1}$ was calculated from the lowest post-PBS value to the lowest post-histamine value and the histamine $\mathrm{PC}_{20}$ was calculated by interpolation of the last two data points on the concentration-response curve. ${ }^{8}$

\section{ALLERGEN INHALATION TEST}

Controlled allergen inhalation tests were carried out as previously described. ${ }^{12}$ On day 1 , the control day, subjects waited in the laboratory for at least 30 minutes before performing triplicate $\mathrm{FEV}_{1}$ man- oeuvres. Sterile isotonic buffered saline with $0.5 \%$ phenol, the diluent for the allergen solutions, was nebulised by a separate Wright nebuliser (output $0.130 \mathrm{ml} / \mathrm{min}$, flow rate $8.51 \mathrm{~min}^{-1}$ ) and inhaled via a mouthpiece and Hans Rudolph valve with two filters (BB-50T, Pall Biomedical Inc, Fajardo, Puerto Rico 00648 ) in series on the exhaled line. Three two minute tidal breathing inhalations of diluent were done at 10 minute intervals, the $\mathrm{FEV}_{1}$ being repeated in duplicate 10 minutes after each inhalation and then 20,30 , 40, 50, 60, 90 minutes and 2, 3, 4, 5, 6, and 7 hours after the final inhalation. The best $\mathrm{FEV}_{1}$ at each time was retained for analysis. Histamine $\mathrm{PC}_{20}$ and the allergen concentration required to produce a $2 \mathrm{~mm}$ skin weal were determined during day 1 and these allowed prediction of the allergen $\mathrm{PC}_{20} \cdot{ }^{9}$

On day 2 , usually the next morning, allergen inhalation was performed. In a fashion analogous to diluent inhalation, doubling amounts of the relevant aqueous allergen, beginning three dilutions below the predicted allergen $\mathrm{PC}_{20}$, were inhaled for two minutes at 10 minute intervals until the $\mathrm{FEV}_{1}$ had fallen at least $20 \%$; the $\mathrm{FEV}_{1}$ was then followed for seven hours as on day 1 . The percentage fall in $\mathrm{FEV}_{1}$ was calculated from the highest baseline to the highest post-allergen $\mathrm{FEV}_{1}$.

\section{STUDY DESIGN}

Subjects attended the laboratory on two days (which were usually consecutive) for control and allergen inhalation tests. All had a stable FEV $1 \leqslant 10 \%$ difference between the two days), none had suffered 
Table 2 Individual values ( $\mathrm{mg} / \mathrm{ml}$ ) for histamine provocative concentration causing a $20 \%$ fall in $F E V_{1}\left(P C_{20}\right)$

\begin{tabular}{|c|c|c|c|c|c|c|c|c|c|c|}
\hline \multirow[b]{2}{*}{ Patient No } & \multirow[b]{2}{*}{ Control } & \multicolumn{2}{|c|}{ After diluent } & \multicolumn{4}{|c|}{ After allergen } & \multicolumn{3}{|c|}{ Second allergen challenge } \\
\hline & & $2 h$ & $7 h$ & $2 h$ & $7 h$ & $30 h$ & $5-7 d$ & I8h before & 7 h after & $30 \mathrm{~h}$ after \\
\hline $\begin{array}{l}\text { DUAL RESPONDERS } \\
3 \\
4 \\
5 \\
7 \\
8 \\
11 \\
12 \\
13 \\
14 \\
15 \\
16 \\
19\end{array}$ & $\begin{array}{l}5 \cdot 4 \\
3 \cdot 8 \\
3 \cdot 8 \\
2 \cdot 1 \\
1.2 \\
0 \cdot 58 \\
0 \cdot 40 \\
0 \cdot 40 \\
0 \cdot 36 \\
0.32 \\
0 \cdot 20 \\
0 \cdot 12\end{array}$ & $\begin{array}{l}7.9 \\
3.4 \\
9.0 \\
1.9 \\
1.3 \\
0.62 \\
0.59 \\
0.33 \\
0.23 \\
0.34 \\
0.80 \\
0.12\end{array}$ & $\begin{array}{l}5 \cdot 1 \\
7 \cdot 2 \\
8 \cdot 8 \\
3 \cdot 1 \\
1 \cdot 3 \\
0 \cdot 49 \\
0 \cdot 34 \\
0 \cdot 30 \\
0 \cdot 21 \\
0 \cdot 39 \\
0 \cdot 20 \\
0 \cdot 15\end{array}$ & $\begin{array}{l}2 \cdot 8 \\
4 \cdot 2 \\
2 \cdot 6 \\
2 \cdot 3 \\
1 \cdot 3 \\
0 \cdot 46 \\
0 \cdot 30 \\
0 \cdot 29 \\
0 \cdot 17 \\
0 \cdot 37 \\
0 \cdot 18 \\
0 \cdot 19\end{array}$ & $\begin{array}{l}1.7 \\
1.8 \\
0.9 \\
0.71 \\
0.30 \\
0.29 \\
0.37 \\
0.045 \\
0.10 \\
0.15 \\
0.052 \\
0.024\end{array}$ & $\begin{array}{l}3.9 \\
4 \cdot 1 \\
1.4 \\
2.7 \\
0.50 \\
0.22 \\
0.15 \\
0.26 \\
0.13 \\
0.35 \\
0.096 \\
0.048\end{array}$ & $\begin{array}{l}7 \cdot 9 \\
3 \cdot 1 \\
3.1 \\
2.9 \\
1.0 \\
0 \cdot 37 \\
0.80 \\
0 \cdot 22 \\
0 \cdot 18 \\
0.41 \\
0 \cdot 13\end{array}$ & $\begin{array}{l}9.3 \\
2.8 \\
6.5 \\
3.4 \\
1.4 \\
0.37 \\
0.48 \\
0.37 \\
0.25 \\
- \\
\overline{0} \\
0.15\end{array}$ & $\begin{array}{l}3 \cdot 7 \\
1 \cdot 5 \\
0 \cdot 22 \\
0 \cdot 70 \\
0 \cdot 23 \\
0 \cdot 17 \\
0 \cdot 19 \\
0 \cdot 14 \\
0 \cdot 12 \\
- \\
- \\
0 \cdot 030\end{array}$ & $\begin{array}{l}4.2 \\
1.8 \\
1.9 \\
1.6 \\
0.41 \\
0.24 \\
0.13 \\
0.25 \\
0.19 \\
- \\
- \\
0.078\end{array}$ \\
\hline $\begin{array}{l}\text { Geometric mean } \\
\mathrm{PC}_{20}\end{array}$ & $0 \cdot 78$ & 0.95 & $0 \cdot 86$ & 0.67 & $0 \cdot 24^{* *}$ & $0 \cdot 44^{* *}$ & 0.83 & 1.07 & $0 \cdot 28$ & 0.51 \\
\hline $\begin{array}{l}\text { EARLY RESPONDERS } \\
1 \\
2 \\
6 \\
9 \\
10 \\
17 \\
18\end{array}$ & $\begin{array}{l}8 \\
7 \cdot 2 \\
2 \cdot 5 \\
1 \cdot 2 \\
0 \cdot 8 \\
0 \cdot 20 \\
0 \cdot 17\end{array}$ & $\begin{array}{l}8 \\
7 \cdot 2 \\
1 \cdot 0 \\
1 \cdot 7 \\
1 \cdot 1 \\
0 \cdot 18 \\
0 \cdot 10\end{array}$ & $\begin{array}{l}3 \cdot 5 \\
6.8 \\
2 \cdot 6 \\
0.9 \\
1 \cdot 3 \\
0 \cdot 35 \\
0 \cdot 09\end{array}$ & $\begin{array}{l}3 \cdot 8 \\
4.5 \\
1 \cdot 6 \\
1.8 \\
4 \cdot 0 \\
0 \cdot 22 \\
0 \cdot 06\end{array}$ & $\begin{array}{l}2 \cdot 7 \\
2 \cdot 5 \\
3 \cdot 8 \\
1 \cdot 1 \\
1 \cdot 3 \\
0 \cdot 16 \\
0 \cdot 19\end{array}$ & $\begin{array}{l}4.8 \\
5.9 \\
1.8 \\
2 \cdot 2 \\
1.4 \\
0 \cdot 20 \\
0 \cdot 19\end{array}$ & $\begin{array}{l}E \\
= \\
= \\
=\end{array}$ & & & \\
\hline $\begin{array}{l}\text { Geometric mean } \\
\text { PC }_{20}\end{array}$ & $1 \cdot 24$ & $1 \cdot 10$ & $1 \cdot 12$ & $1 \cdot 15$ & $1 \cdot 02$ & $1 \cdot 29$ & & & & \\
\hline $\begin{array}{l}\text { TOTAL GROUP } \\
\log \mathrm{PC}_{20} \\
\text { n } \\
\text { Mean } \\
\text { SD } \\
\text { Geometric mean }\end{array}$ & $\begin{array}{c}19 \\
-0.033 \\
0.60 \\
0.93\end{array}$ & $\begin{array}{l}19 \\
0.001 \\
0.63 \\
1.00\end{array}$ & $\begin{array}{c}19 \\
-0.023 \\
0.63 \\
0.95\end{array}$ & $\begin{array}{r}19 \\
-0.09 \\
0.60 \\
0.81\end{array}$ & $\begin{array}{c}19 \\
-0.38 \\
0.66 \\
0.42^{* *}\end{array}$ & $\begin{array}{l}18 \\
-0.15 \\
0.67 \\
0.70^{*}\end{array}$ & & & & \\
\hline
\end{tabular}

${ }^{*} p<0.01 ;{ }^{* *} p<0.001$ compared with $7 \mathrm{~h}$ after saline.

allergen exposure or respiratory tract infection for at least four weeks, and all were able to withhold inhaled $\beta_{2}$ agonists for at least eight hours.

Histamine $\mathrm{PC}_{20}$ was measured six or seven times in all subjects. A baseline $\mathbf{P C}_{20}$ was obtained within two weeks of the study. Histamine inhalation was repeated, starting two and seven hours after completion of diluent inhalation on day 1 and two, seven, and 30 hours after allergen inhalation on day 2 . In all cases the two hour histamine inhalation test was completed in less than 30 minutes and was therefore completed 2.25-2.5 hours after allergen inhalation. In subjects with a late asthmatic response and a significant reduction in histamine $\mathrm{PC}_{20}$ a seventh histamine inhalation test was done five to seven days later.

Ten subjects with equivocal or definite dual asthmatic responses underwent repeat allergen challenge within two months of the original study. The same dose of allergen was administered 10 minutes after inhalation of two puffs of freon propellant. Histamine $\mathrm{PC}_{20}$ was measured before and seven and 30 hours after allergen challenge but not at two hours.

ANALYSIS

Analysis was performed by means of logarithmic transformation of $\mathrm{PC}_{20}$ values and paired $t$ tests. ${ }^{10}$

\section{Results}

There was less than $5 \%$ change in $\mathrm{FEV}_{1}$ during the control day in 17 of the 19 subjects. In the remaining two (Nos 16 and 18) there was a gradual fall in FEV F $_{1} \stackrel{?}{?}$ of $15-20 \%$. A correction was made for the presence 0 and magnitude of the late response in these two subjects in the allergen study.

After allergen challenge in the 19 subjects the mean early fall in FEV 1 was $24.5 \%$ (SD 8.86\%). A definite early asthmatic response $\left(>15 \%\right.$ fall in $\left.\mathrm{FEV}_{1}\right)$ was seen in 18 and an equivocal (5-15\%) response in one 

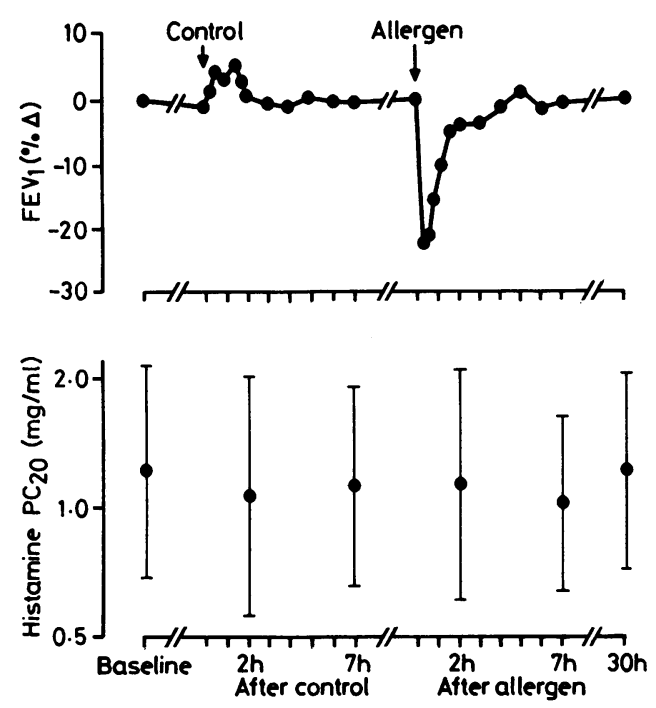

Fig 1 Changes in $F E V_{1}$ and histamine $P C_{20}$ (provocative concentration causing a $20 \%$ fall in $F E V_{1}$ ) in seven subjects with an isolated early asthmatic response. The mean FEV (\% change) in the upper graph and the geometric mean (with $S E M)$ histamine $P C_{20}$ in the lower graph are plotted against time (variable scale) on the horizontal axis.

subject. This subject was included because he had a reproducible late response with an associated fall in histamine $\mathrm{PC}_{20}$. The mean late fall in $\mathrm{FEV}_{1}$ was $11.8 \%(10.9 \%)(\mathrm{p}<0.001)$. There was a definite late response $(>15 \%)$ in seven subjects, an equivocal late response $(5-15 \%)$ in five, and no late response $(<5 \%)$ in seven subjects.

\section{CHANGES IN HISTAMINE PC $_{20}$ AFTER ALLERGEN CHALLENGE}

Changes in histamine $\mathrm{PC}_{20}$ seven and 30 hours after allergen challenge were compared with those occurring seven hours after saline and with prior "baseline" measurements in all 19 subjects (table 2). Geometric mean histamine $\mathrm{PC}_{20}$ values were $0.93 \mathrm{mg} / \mathrm{ml}$ at baseline, $0.95 \mathrm{mg} / \mathrm{ml}$ seven hours after saline, $0.42 \mathrm{mg} / \mathrm{ml}$ seven hours after allergen, and $0.70 \mathrm{mg} / \mathrm{ml}(\mathrm{n}=18)$ 30 hours after allergen. Mean and SD log histamine $\mathrm{PC}_{20}$ values are shown in table 2 . The values seven and 30 hours after allergen were significantly lower than those seven hours after saline $(p<0.001$ and $p$ $=0.01$ respectively). In six of the seven subjects with an isolated early response there was less than a twofold reduction in $\mathrm{PC}_{20}$ at both seven and 30 hours after allergen compared with seven hours after saline. On the other hand, all 12 subjects with either a definite or an equivocal late response showed a greater than twofold reduction in $\mathrm{PC}_{20}$ at either seven hours $(n=10)$ or 30 hours $(n=6)$ following allergen. Despite a trend for larger falls in histamine $\mathrm{PC}_{20}$ with larger late responses to allergen there was no significant correlation in this study, nor was there any difference between mean $\Delta \log \mathrm{PC}_{20}$ in the seven definite and five equivocal late responders. The 12 definite and equivocal late responders were therefore compared with the seven early responders; the late responders had an early response of $26.3 \%$ (SD $9.8 \%$ ) fall in $\mathrm{FEV}_{1}$ and a late response of $17.4 \%$ $(10.5 \%)$ compared with $22 \cdot 3 \%(6.6 \%)$ and $2.5 \%$ $(2.0 \%)$ for the early responders.

\section{EARLY VERSUS DUAL RESPONDERS}

In the seven early responders the geometric mean histamine $\mathrm{PC}_{20}$ was $1.0-1.3 \mathrm{mg} / \mathrm{ml}$ on all six occasions (fig 1). In the 12 subjects with a dual response the geometric mean histamine $\mathrm{PC}_{20}$ values showed little fluctuation between baseline, two and seven hours after the control challenge, and five to seven days after allergen, ranging from 0.74 to $0.95 \mathrm{mg} / \mathrm{ml}$. Two hours after allergen, when the $\mathrm{FEV}_{1}$ was reduced by $5.2 \%(\mathrm{SD} 5 \cdot 7 \%)$, there was a small reduction in geometric mean $\mathrm{PC}_{20}$ to $0.67 \mathrm{mg} / \mathrm{ml}$, which was nonsignificant when compared with two hours after diluent $(p>0.05)$. The small reduction was due largely to three subjects in whom $\mathrm{PC}_{20}$ fell slightly more than twofold; in the remaining nine subjects the change was less than twofold. At seven hours the

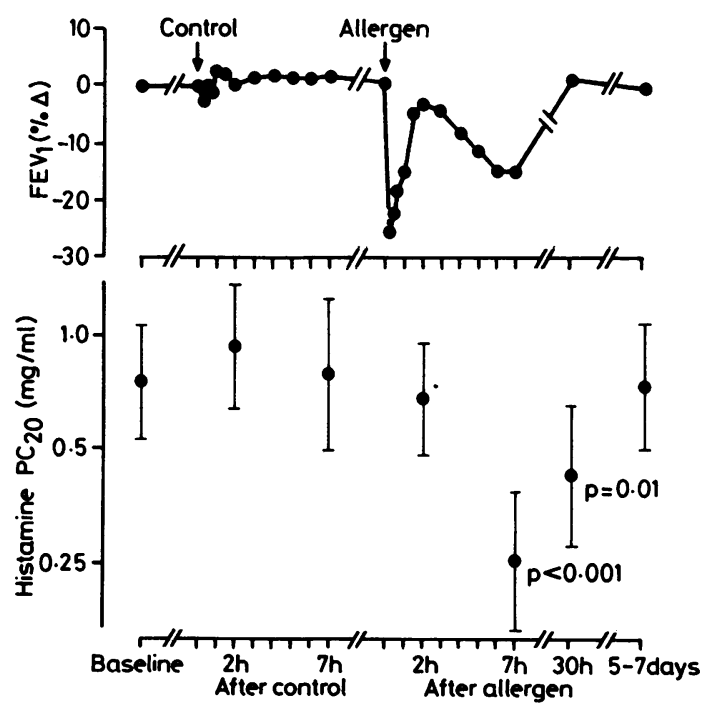

Fig 2 Changes in FEV and histamine $P C_{20}$ (see fig 1) in 12 subjects with a dual asthmatic response. The mean $F E V_{1}$ (\% change) in the upper graph and the geometric mean (with $S E M)$ histamine $P C_{20}$ in the lower graph are plotted against time (variable scale) on the horizontal axis. 
$\mathrm{FEV}_{1}$ was reduced by $13.7 \%$ (SD 10\%) $(\mathrm{p}<0.001)$ and the histamine $\mathrm{PC}_{20}$ was reduced almost fourfold to $0.24 \mathrm{mg} / \mathrm{ml}(\mathrm{p}<0.001)$. At 30 hours the $\mathrm{FEV}_{1}$ was back to baseline but the $\mathrm{PC}_{20}$ was still reduced almost twofold to $0.44 \mathrm{mg} / \mathrm{ml}(\mathrm{p}<0.01)$. Changes in FEV and histamine $\mathrm{PC}_{20}$ in subjects with a dual response are shown in figure 2 .

\section{REPEAT ANTIGEN STUDIES}

In the 10 dual responders undergoing a repeat antigen challenge the repeat values for the early response $(30.2 \%$ (SD $15.8 \%) \vee 26 \cdot 3 \%(9.8 \%))$, late response $(21.8 \%(13.6 \%) \vee 17.4 \%(10.5 \%)), \Delta \log \mathrm{PC}_{20}$ at seven hours $(0.58(0.36) v 0.55(0.31))$, and $\Delta \log \mathrm{PC}_{20}$ at 30 hours $(0.32 \quad(0.16) \quad v \quad 0.31 \quad(0.15))$ were reproducible. This suggests that the performance of a histamine test two hours after allergen challenge did not affect the subsequent development (or magnitude) of the late response, or change histamine responsiveness.

\section{Discussion}

These data show that non-allergic bronchial responsiveness to histamine had not increased when measured 2-2.5 hours after allergen exposure in nine of 12 subjects with subsequent allergen induced late responses. The three subjects who had a fall in histamine $\mathbf{P C}_{20}$ slightly more than twofold did not have unusually large $(12 \%, 22 \%$, and $24 \%)$ or unusually early late responses.

Non-allergic bronchial responsiveness to histamine and cholinergic agonists has been shown to increase after both natural ${ }^{31-14}$ and artificial (laboratory) 1245 exposure to both allergens and occupational sensitising chemicals. This is sometimes maximal seven to eight hours after exposure, when reduced airway calibre may play a role in increased responsiveness. ${ }^{1-2}$ Non-allergic responsiveness, however, may continue to increase for several days ${ }^{12}$ and may remain increased after sensitive tests of airway function have returned to baseline. ${ }^{24}$ To our knowledge there are no fully published data regarding changes in bronchial responsiveness preceding the late asthmatic response. Milillo stated, during a conference discussion, that his group had observed increased non-specific responsiveness three hours after allergen challenge. ${ }^{15}$ Recently Durham et al have reported in abstract form increased responsiveness to histamine after two to three hours in six subjects with late asthmatic responses to occupational challenges. ${ }^{16}$ These observations are not incompatible with our own. The current data, combined with those from previous studies, ${ }^{12}$ lead to the conclusion that bronchial responsiveness in late responders must develop between two and seven hours after allergen exposure. It is therefore not surprising that significant changes may have occurred by three hours. In fact, the observation of probablyo significant falls in histamine $\mathrm{PC}_{20}$ in three of our 12 음 subjects at two hours supports the idea that increased $\frac{\bar{s}}{\frac{5}{6}}$ responsiveness may develop between two and three to $\mathbb{\Omega}_{\Omega}$ four hours after exposure, which is before the lateor response occurs. The studies in occupationals asthma $^{16}$ may not, however, be entirely analogous. The immunopathology of many of these remains $\vec{\omega}$ somewhat obscure and the late or non-immediateo asthmatic responses are more common, may begin $\overrightarrow{\times}$ earlier, and may last longer than those that followi allergen exposure. ${ }^{1718}$

Both the late responses and the changes in bronchial responsiveness to histamine were substantially smaller in this study than in previous studies. ${ }^{12}$ Pre-음 vious observations suggest that more severe lateresponses start earlier and last longer. Possibly there $=\frac{D}{0}$ fore more severe late asthmatic responses are associated with earlier changes in histamine responsiveness. $\overrightarrow{0}$ Such a trend was not observed in our study. The most severe late responses, $40 \%$ and $32 \%$ falls in $\mathrm{FEV}_{1}$, were not associated with an early change in $\mathrm{PC}_{20}$; while the three subjects with a greater than twofold fall in $\mathrm{PC}_{20}$ two hours after allergen did not have?

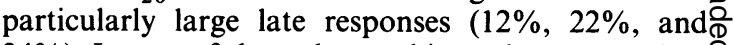
$24 \%$ ). In two of these three subjects the greater than twofold $\mathrm{PC}_{20}$ difference from the value two hourso을 after diluent was due to an unexpected high $\mathrm{PC}_{20} \frac{3}{5}$ value after diluent; neither showed a twofold change when the two hour value was compared with the baseline determination.

The precise pathophysiology of the late asthmatic response and associated transient increases in airways ${ }_{-}^{x}$ responsiveness remains uncertain. Early speculation 3 . that a type III immune response played a part ${ }^{17}$ was not supported by clinical and laboratory data. ${ }^{19}$ Late 3 cutaneous allergic responses, which are likely to be of similar immune pathogenesis, appear to be $\operatorname{IgE} \mathrm{E}^{\mathrm{S}}$ dependent. $^{2021}$ While the exact mediator or media- -0 tors and cells that are concerned in the late responses are unknown, there is presumptive evidence to sug- $\sigma$ gest that inflammation and oedema ${ }^{2223}$ in addition to bronchoconstriction play a part in its pathogenesis. N Inflammation is also likely to be the cause of non- $\sigma$ allergic airway responsiveness. ${ }^{24}$ We propose the hypothesis that the allergen induced late asthmatic response and allergen induced increase in bronchial responsiveness to histamine are both manifestations ${ }_{0}$ of underlying airway inflammation. There are some

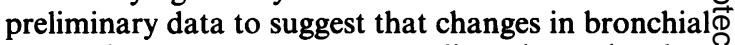
responsiveness may occur earlier than the late $\frac{}{\mathbb{D}}$ response. Significant changes in histamine $\mathrm{PC}_{20}$ have $\varrho$ occurred, in this study and others, ${ }^{12}$ in subjects with a very small (5-15\% $\mathrm{FEV}_{1}$ reduction) late responseᄋ 
that would have been ignored previously. In an occupational setting reductions in $\mathrm{PC}_{20}$ have been documented in two patients in the absence of any change in $\mathrm{FEV}_{1},{ }^{25} 26$ although one of these had a late response to a larger occupational exposure. ${ }^{26}$ These data, in addition to the three hour data ${ }^{1516}$ and the observations that changes in non-allergic responsiveness persist after any measurable alteration in lung function has resolved, ${ }^{24}$ suggest that changes in airway responsiveness may be a more subtle or more sensitive reflection of "allergen induced late airways inflammation" than the late asthmatic response.

In summary, we have confirmed that allergen induced isolated early asthmatic responses, with less than a 5\% late asthmatic response, are not associated with change in non-allergic bronchial responsiveness to inhaled histamine two, seven, or 30 hours after exposure. Twelve subjects with allergen induced dual asthmatic responses were significantly more responsive to inhaled histamine seven and 30 hours but not two hours or five to seven days after allergen inhalation. The increase in non-allergic bronchial responsiveness appears to develop with, or perhaps slightly before, the late asthmatic response, persists beyond any measurable late response, and may appear after or during subclinical late asthmatic responses. It is suggested that allergen induced late asthmatic responses and allergen induced increases in non-allergic bronchial responsiveness are both manifestations of allergen induced inflammatory changes occurring in the airways, and that the changes in responsiveness may be more sensitive - that is, may appear without and persist beyond the late response.

We would like to thank B Gore and J Bramley for the preparation of this manuscript. The work was supported by grants from the Medical Research Council of Canada (MA7051) and from Fisons Pharmaceuticals Canada Ltd.

\section{References}

1 Cockcroft DW, Ruffin RE, Dolovich J, Hargreave FE. Allergen-induced increase in nonallergic bronchial reactivity. Clin Allergy 1977;7:503-13.

2 Cartier A, Thomson NC, Frith PA, Roberts R, Hargreave FE. Allergen-induced increase in bronchial responsiveness to histamine: relationship to the late asthmatic response and change in airway caliber. $J$ Allergy Clin Immunol 1982;70:170-7.

3 Boulet LP, Cartier A, Thomson NC, Roberts RS, Dolovich $J$, Hargreave FE. Asthma and increases in nonallergic bronchial responsiveness from seasonal pollen exposure. J Allergy Clin Immunol 1983;71:399-406.

4 Cockcroft DW, Cotton DJ, Mink JT. Nonspecific bronchial hyperreactivity after exposure to Western red cedar: a case report. Am Rev Respir Dis 1979; 119:505-10.

5 Lam S, Wong R, Yeung M. Nonspecific bronchial reactivity in occupational asthma. J Allergy Clin Immunol 1979;63:28-34.

6 Cockcroft DW, Killian DN, Mellon JJA, Hargreave FE. Bronchial reactivity to inhaled histamine: a method and clinical survey. Clin Allergy 1977;7:235-43.

7 Juniper EF, Frith PA, Dunnett C, Cockcroft DW, Hargreave FE. Reproducibility and comparison of responses to inhaled histamine and methacholine. Thorax 1978;33:705-10.

8 Cockcroft DW, Murdock KY, Mink JT. Determination of histamine $\mathrm{PC}_{20}$ : comparison of linear and logarithmic interpolation. Chest 1983;84:505-6.

9 Hargreave FE, Cockcroft DW, Ruffin RE, Dolovich J. Prediction of the dose of inhaled allergen required to produce a threshold experimental asthmatic response [abstract]. J Allergy Clin Immunol 1978;61:194.

10 Steel RDG, Torrie JH. Principles and procedures of statistics: a biometrical approach. 2nd ed. New York: McGraw-Hill Book Co, 1980:102-4.

11 Altounyan REC. Changes in histamine and atropine responsiveness as a guide to diagnosis and evaluation of therapy in obstructive airways disease. In: Pepys J, Franklands AW, eds. Disodium cromoglycate in allergic airways disease. London: Butterworths, 1970: 47-53.

12 Lowhagen O, Rak S. Modification of bronchial hyperreactivity after treatment with sodium cromoglycate during pollen season. $J$ Allergy Clin Immunol 1985;75:460-7.

13 Sotomayer H, Badier M, Vervloet D, Orehek J. Seasonal increase of carbachol airway responsiveness in patients allergic to grass pollen. Am Rev Respir Dis 1984;130:56-8.

14 Cartier A, Pineau L, Malo JL. Monitoring of maximum expiratory peak flow rates and histamine inhalation tests in the investigation of occupational asthma. Clin Allergy 1984;14:193-6.

15 Milillo G. Discussion. In: Proceedings of International Conference on Bronchial Hyperreactivity. Oxford: Medicine Publishing Foundation, 1982:17.

16 Durham SR, Graneek BJ, Hawkins R, Newman-Taylor AJ. The temporal relationship between airway reactivity and late asthmatic reactions induced by occupational agents [abstract]. Thorax 1985;40:703.

17 Pepys J. Immunopathology of allergic lung disease. Clin Allergy 1973;3:1-22.

18 Pepys J, Hutchcroft BJ. Bronchial provocation tests in etiologic diagnosis and analysis of asthma. Am Rev Respir Dis 1975;112:829-59.

19 Booij-Noord H, deVries K, Sluiter HJ, Orie NGM. Late bronchial obstructive reaction to experimental inhalation of house dust extract. Clin Allergy 1972;2:43-61.

20 Dolovich J, Hargreave FE, Chalmers R, Shier KJ, Gauldie J, Bienenstock J. Late cutaneous allergic responses in isolated IgE-dependent reactions. $J$ Allergy Clin Immunol 1973;52:38-46.

21 Solley GO, Gleich CJ, Jordan RE, Schroeter AL. The late phase of the immediate wheal and flare skin reac- 
tion. J Clin Invest 1976;58:408-20.

22 Cockcroft DW. Mechanism of perennial allergic asthma. Lancet 1983;ii:253-6.

23 Kaliner M. Hypotheses on the contribution of late-phase allergic responses to the understanding and treatment of allergic diseases. J Allergy Clin Immunol 1984; 73:311-5.

24 Nadel JA, Holtzman MJ. Regulation of airway responsiveness and secretion: role of inflammation. In: Kay AB, Austen KF, Lichtenstein LM, eds. Asthma: physiology, immunopharmacology and treatment. London: Academic Press, 1984:129-55.

25 Cockcroft DW, Hoeppner VH, Dolovich J.ర Occupational asthma caused by cedar urea for-등 maldehyde particle board. Chest 1982;82:49-53.

26 L'Archeveque J, Malo JL, Cartier A. Time course of the changes in histamine bronchial responsiveness after an antigen challenge which did not cause significantôn changes in airway caliber [abstract]. J Allergy ClinImmunol 1986;77:170. 